\title{
Incorporation of sugarcane bagasse ash waste as an alternative raw material for red ceramic
}

\section{(Incorporação de resíduo de cinzas de bagaço de cana-de-açúcar como uma matéria-prima alternativa para cerâmica vermelha)}

\author{
K. C.P. Faria, J. N. F. Holanda \\ Grupo de Materiais Cerâmicos/LAMAV-CCT, Universidade Estadual do Norte Fluminense Darcy Ribeiro, \\ Av. Alberto Lamego 2000, Campos dos Goytacazes, RJ, 28013-602, Brazil \\ katiacpfaria@hotmail.com,jose.holanda@pesquisador.cnpq.br
}

\begin{abstract}
The sugarcane industry generates huge amounts of sugarcane bagasse ashes (SCBA). This work investigates the incorporation of a SCBA waste as an alternative raw material into a clay body, replacing natural clay material by up to 20 wt. $\%$. Clay ceramic pieces were produced by uniaxial pressing and fired at temperatures varying from 700 to $1100{ }^{\circ} \mathrm{C}$. The technological properties of the clay ceramic pieces (linear shrinkage, apparent density, water absorption, and tensile strength) as function of the firing temperature and waste addition are investigated. The phase evolution during firing was followed by X-ray diffraction. The results showed that the SCBA waste could be incorporated into red ceramics (bricks and roofing tiles) in partial replacement for natural clay material. These results confirm the feasibility of valorisation of SCBA waste to produce red ceramic. This use of SCBA can also contribute greatly to reducing the environmental problems of the sugarcane industry, and also save the sources of natural raw materials used in the ceramic industry.
\end{abstract}

Keywords: sugarcane bagasse ash, waste, red ceramic, recycling.

\section{Resumo}

\begin{abstract}
A indústria de cana-de-açúcar gera enormes quantidades de cinzas de bagaço de cana-de-açúcar (CBCA). Este trabalho investiga a incorporação de um resíduo de CBCA como uma matéria-prima alternativa numa massa argilosa substituindo material de argila natural por até $20 \%$ em peso. Peças de cerâmica vermelha foram produzidas por prensagem uniaxial e queimadas em temperaturas entre 700 e $1100{ }^{\circ} \mathrm{C}$. As propriedades tecnológicas das peças de cerâmica vermelha (retração linear, massa específica aparente, absorção de água e resistência à tração) como uma função da temperatura de queima e adição de resíduo de CBCA são investigadas. A evolução das fases durante o processo de queima foi acompanhada via difração de raios $X$. Os resultados mostraram que o resíduo de CBCA poderia ser incorporado em cerâmica vermelha (blocos cerâmicos e telhas) em substituição parcial do material de argila natural. Estes resultados confirmam a viabilidade de valorização do resíduo de CBCA em cerâmica vermelha. Este uso de resíduo de CBCA pode contribuir significativamente para redução dos problemas ambientais da indústria de cana-de-açúcar e, também, economizar as fontes de matérias-primas naturais usadas na indústria cerâmica.

Palavras-chave: cinza de bagaço de cana-de-açúcar, resíduo, cerâmica vermelha, reciclagem.
\end{abstract}

\section{INTRODUCTION}

Sugarcane is grown in over 110 countries. Brazil is the world's largest producer of sugarcane, followed by India, China, and Thailand. It is estimated that the Brazilian sugarcane production will reach 597 million tons in the 2012/2013 crop [1]. This industry is based mainly on the production of sugar and ethanol, which generates huge amounts of sugarcane bagasse. The bagasse is the matted cellulose fiber waste, whose composition is about 26.6-54.3 $\%$ cellulose, $22.3-29.7 \%$ hemicellulose, and $14.3-24.5 \%$ lignin [2]. This waste material is mainly reused in the same industry as fuel in boilers for energy co-generation [3]. As a result, the sugarcane industry produces huge amounts of a solid waste material known as sugarcane bagasse ash
(SCBA) worldwide.

According with FIESP [4], each ton of bagasse is estimated to produce $25 \mathrm{~kg}$ of residual SCBA. The Brazilian sugarcane industry alone generates around 4 million tons per year of SCBA. So far, the final solution for this solid waste has been mainly its use as soil fertilizer. Only seldom it is utilized further. This is not a safe solution for final disposal of this abundant waste, because it causes significant changes in the physico-chemical characteristics of the soils and environmental problems. Thus, efforts should be done in order to find a permanent solution for the final disposal and valorization of this solid waste material in an ecological and economical way. The ceramic industry uses huge amounts of natural raw materials for the manufacture of clay-based products [5-7]. This fact, however, has brought 
the ceramic industry to face scarcity of good quality raw materials in locations close to the plants [8]. The SCBA waste is mainly composed of silicon oxide $\left(\mathrm{SiO}_{2}\right)$, with other minor components such as aluminum, iron, calcium, and potassium oxides [9]. Thus, SCBA waste is very similar in terms of chemical composition to common clays used in the production of red ceramic. This means that the reuse of SCBA waste as a possible raw material for red ceramic is an important technological solution [10-13]. However, in spite of the fact that SCBA waste was produced in large amounts every year, insufficient attention was devoted to the incorporation of SCBA waste in the production of red ceramic.

The aim of this study is to investigate the suitability of incorporation of SCBA waste as a low cost raw material in the production of red ceramic.

\section{MATERIALS AND METHODS}

The raw materials used were common clay and SCBA waste. The common clay used was provided by a local red ceramic industry. The SCBA waste sample was colleted from a sugarcane mill located in south-eastern Brazil (Campos dos Goytacazes, RJ). Both samples in the form of granular powder were dried $\left(110{ }^{\circ} \mathrm{C}\right)$, and then sieved until a fraction passing in a 42 mesh $(<355 \mu$ m ASTM $)$ sieve. Coarser particles were rejected. The chemical compositions of the raw materials were determined by energy-dispersive $\mathrm{X}$-ray spectrometer (EDX 700, Shimadzu). The loss on ignition was determined by calculating the wt.\% difference between a sample dried at $110^{\circ} \mathrm{C}$ and a sample calcined at $1000^{\circ} \mathrm{C}$ during $2 \mathrm{~h}$.

Mineralogical analysis of the raw materials was performed by X-ray diffraction (XRD 7000, Shimadzu), with monochromatic $\mathrm{Cu}-\mathrm{k} \alpha$ radiation at a scanning speed $1.5^{\circ} 2 \theta / \mathrm{min}$ over non-oriented specimens. The crystalline phases were identified by comparing the intensities and positions of the Bragg peaks with those listed in the JCPDSICDD files.

The particle size analysis of the raw materials was determined according to the NBR 7181-84 standard. The plastic properties were obtained through the Atterberg consistency limits according to the Brazilian standards (NBR 6459-84 and NBR 7180-84).

Table I - Clayey formulations utilized (wt.\%). [Tabela I - Formulações argilosas utilizadas (\% em peso).]

\begin{tabular}{ccc}
\hline & \multicolumn{2}{c}{ Raw Materials } \\
\cline { 2 - 3 } Formulations & Clay & $\begin{array}{c}\text { SCBA } \\
\text { Waste }\end{array}$ \\
\hline KC0 & 100 & 0 \\
KC5 & 95 & 5 \\
KC10 & 90 & 10 \\
KC15 & 85 & 15 \\
KC20 & 80 & 20 \\
\hline
\end{tabular}

Five different clay/SCBA waste mixtures were prepared (Table I). The additions of SCBA waste were up to $20 \mathrm{wt} . \%$ in gradual replacement of common clay. The clayey compositions were mixed and homogenized in a cylindrical mixer for $30 \mathrm{~min}$. The moisture content was adjusted to $7 \mathrm{wt} . \%$ water (moisture mass/dry mass).

The ceramic pieces in form of disks ( $25 \mathrm{~mm}$ diameter) were uniaxially pressed at $21 \mathrm{MPa}$, and then dried at $110{ }^{\circ} \mathrm{C}$ for $24 \mathrm{~h}$. The firing step was carried out at soaking temperatures varying from 700 to $1100{ }^{\circ} \mathrm{C}$, using a slowfiring cycle of total duration of $24 \mathrm{~h}$ (cold-to-cold). Heating and cooling rates were controlled.

The ceramic pieces were characterized in terms of linear shrinkage, water absorption, apparent density, and tensile strength. Linear shrinkage values upon drying and firing were evaluated from the variation of the main dimension (diameter) of the pieces. The apparent density values were determined using the Archimedes method of immersion in water. The water absorption values were determined from the weight differences between the as fired and water saturated pieces (immersion in boiling water for $2 \mathrm{~h}$ ). The tensile strength of the fired pieces obtained by the diametral compressive method [14] was determined by using a universal testing machine (model 5582, Instron). The crossbar speed was hold at $0.5 \mathrm{~mm} / \mathrm{min}$ for all tests. Mineralogical analysis of the fired pieces was done via $\mathrm{X}$-ray diffraction. Microstructural analysis was done via scanning electron microscopy.

\section{RESULTS AND DISCUSSION}

The XRD pattern of the SCBA waste is shown in Fig. 1. The following crystalline phases were identified: quartz $\left(\mathrm{SiO}_{2}\right)$, cristobalite $\left(\mathrm{SiO}_{2}\right)$, hydrated calcium phosphate $\left(\mathrm{Ca}_{3}\left(\mathrm{PO}_{4}\right)_{2} \cdot \mathrm{H}_{2} \mathrm{O}\right)$, potassium carbonate $\left(\mathrm{K}_{2} \mathrm{CO}_{3}\right)$, mullite $\left(3 \mathrm{Al}_{2} \mathrm{O}_{3} .2 \mathrm{SiO}_{2}\right)$, and hematite $\left(\mathrm{Fe}_{2} \mathrm{O}_{3}\right)$, with predominance of quartz. For the common clay, as shown in Fig. 2, kaolinite $\left(2 \mathrm{SiO}_{2} \cdot \mathrm{Al}_{2} \mathrm{O}_{3} \cdot 2 \mathrm{H}_{2} \mathrm{O}\right)$ is the dominant clay mineral. Accessory minerals are quartz, gibbsite, goethite, and potash feldspar.

The chemical composition and loss on ignition of the raw materials used are given in Table II. In this table are also given the chemical compositions of SCBA wastes originated from different places. The SCBA waste is constituted mainly by $\mathrm{SiO}_{2}\left(61.59\right.$ wt.\%), followed by $\mathrm{Fe}_{2} \mathrm{O}_{3}, \mathrm{~K}_{2} \mathrm{O}, \mathrm{CaO}$, and $\mathrm{Al}_{2} \mathrm{O}_{3}$ (minor amounts of Ti, $\mathrm{Mg}, \mathrm{Mn}$, and $\mathrm{P}$ oxides). These results are in agreement with the XRD data (Fig. 1). The loss on ignition (LOI) is relatively high (9.78 wt.\%), and is related mainly with the presence of organic matter. The chemical composition of the SCBA waste used in this work, as shown in Table II, is different from the others found in the literature [14-17]. This can be explained in terms of the different soils in which sugarcane grow, fertilization method, and soil management. The commercial common clay showed an expected typical composition rich in $\mathrm{SiO}_{2}$, $\mathrm{Al}_{2} \mathrm{O}_{3}$, and $\mathrm{Fe}_{2} \mathrm{O}_{3}$, with minor amounts of $\mathrm{Ti}, \mathrm{Ca}, \mathrm{Mg}, \mathrm{Mn}$, $\mathrm{K}, \mathrm{Na}$, and $\mathrm{P}$ oxides. The content of iron oxide (8.83 wt.\%) is high, and characterizes the common clay as red firing clay. 


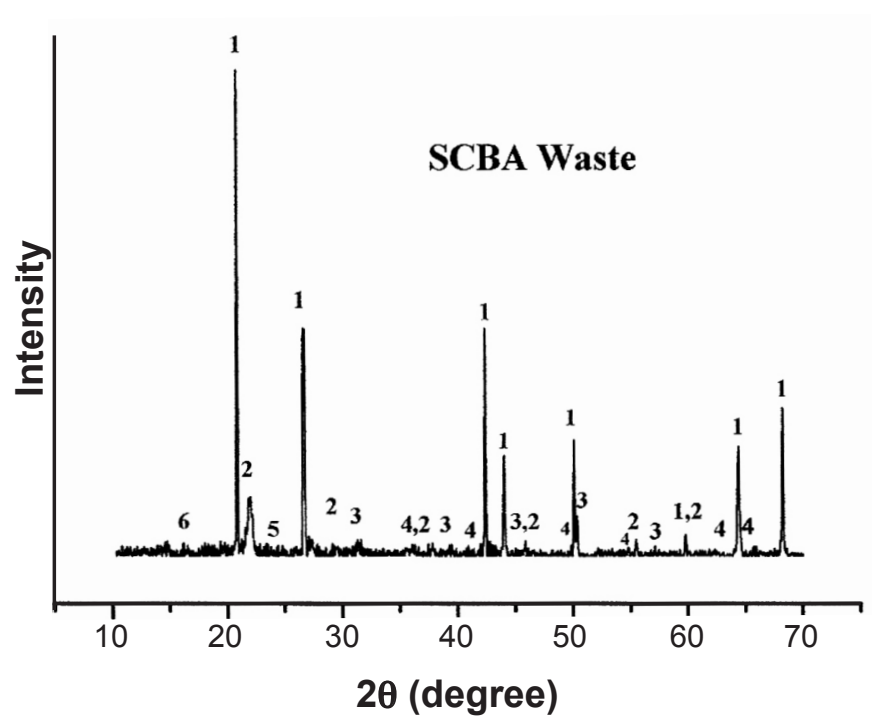

Figure 1: XRD pattern for the SCBA waste sample. 1 - quartz; 2 - cristobalite; 3 - potassium carbonate; 4 - hematite; 5 - calcium phosphate; 6 - mullite.

[Figura 1: Difratograma de raios $X$ da amostra de resíduo de CBCA. 1 - quartzo; 2 - cristobalita; 3 - carbonato de potássio; 4 - hematita; 5 -fosfato de cálcio; 6 - mullita.]

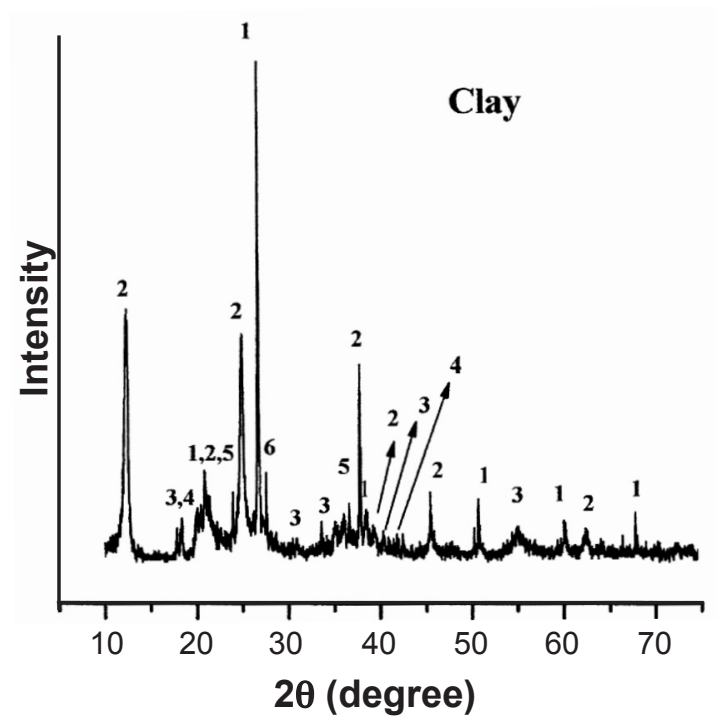

Figure 2: XRD pattern for the common clay sample. 1 - quartz; 2 - kaolinite; 3 - illite/mica; 4 - gibbsite; 5 - goethite; 6 - potash feldspar.

[Figura 2: Difratograma de raios $X$ da amostra de argila. 1 quartzo; 2 - caulinita; 3 - illitalmica; 4 - gibsita; 5 - goetita; 6 -feldspato potássico.

Table II - Chemical composition (wt.\%) of the raw materials.

[Tabela II - Composição química (\% em peso) das matérias-primas.]

\begin{tabular}{|c|c|c|c|c|c|c|}
\hline Oxides & Clay & SCBA Waste & Ref. [15] & Ref. [16] & Ref. [17] & Ref. [18] \\
\hline $\mathrm{SiO}_{2}$ & 43.22 & 61.59 & 72.74 & 59.87 & 60.97 & 83.707 \\
\hline $\mathrm{Al}_{2} \mathrm{O}_{3}^{2}$ & 32.84 & 5.92 & 5.26 & 20.69 & 0.09 & - \\
\hline $\mathrm{Fe}_{2}^{2} \mathrm{O}_{3}^{3}$ & 8.83 & 7.36 & 3.92 & 5.76 & 0.09 & 6.537 \\
\hline $\mathrm{TiO}_{2}^{2}$ & 1.51 & 1.46 & 0.32 & - & - & 1.162 \\
\hline $\mathrm{CaO}^{2}$ & 0.44 & 5.00 & 7.99 & 3.36 & 5.97 & 1.183 \\
\hline $\mathrm{MgO}$ & - & 1.17 & 2.78 & 1.87 & 8.65 & - \\
\hline $\mathrm{MnO}$ & 0.10 & 0.10 & - & - & 0.42 & 0.081 \\
\hline $\mathrm{K}_{2} \mathrm{O}$ & 2.56 & 6.22 & 3.47 & 1.37 & 9.02 & - \\
\hline $\mathrm{Na}_{2} \mathrm{O}$ & - & - & 0.84 & 1.11 & 0.70 & 6.146 \\
\hline $\mathrm{P}_{2} \mathrm{O}_{5}$ & - & 0.98 & 1.59 & - & 8.34 & - \\
\hline $\mathrm{SO}_{3}$ & 1.06 & 0.42 & - & 1.06 & - & 0.682 \\
\hline $\mathrm{ZrO}_{2}$ & - & - & - & - & - & 0.303 \\
\hline $\mathrm{Cr}_{2} \mathrm{O}_{3}$ & - & - & - & - & - & 0.094 \\
\hline $\mathrm{Sc}_{2}^{2} \mathrm{O}_{3}$ & - & - & - & - & - & 0.040 \\
\hline $\mathrm{ZnO}$ & - & - & - & - & - & 0.037 \\
\hline $\mathrm{V}_{2} \mathrm{O}_{5}$ & - & - & - & - & - & 0.029 \\
\hline $\mathrm{LOI}^{+}$ & 9.44 & 9.78 & - & 0.63 & 5.70 & - \\
\hline
\end{tabular}

In addition, the loss on ignition (9.44 wt.\%) is related mainly with the presence of clay minerals, hydroxides, and organic matter.

The data of particle size of the clay/SCBA waste mixtures were plotted in the Winkler's diagram (Fig. 3). The Winkler's diagram is based on the particle size of clay materials, where the vertices represent different particle size ranges $(<2 \mu \mathrm{m}$; $2-20 \mu \mathrm{m}$; and $>20 \mu \mathrm{m}$ ) [19]. According to the Winkler's diagram, it is possible to identify four major regions of claybased products. These regions are: i) region $\mathrm{A}-$ it is adequate for high quality products; ii) region $\mathrm{B}$ - roofing tiles; iii) region $\mathrm{C}$ - hollow floor bricks; and iv) region D - filled floor bricks. As can be observed in Fig. 3, the granulometric behavior of the clayey mixtures has been modified with the SCBA waste additions. The formulation KCO (no SCBA waste added) is placed in the boundary between the A (high quality product) and $\mathrm{B}$ (roofing tiles) regions. The formulation $\mathrm{KC} 10$ showed consistency as raw material of roofing tiles (region B). The formulation $\mathrm{KC} 20$ is placed inside of the characteristic region for hollow floor bricks (region C). 


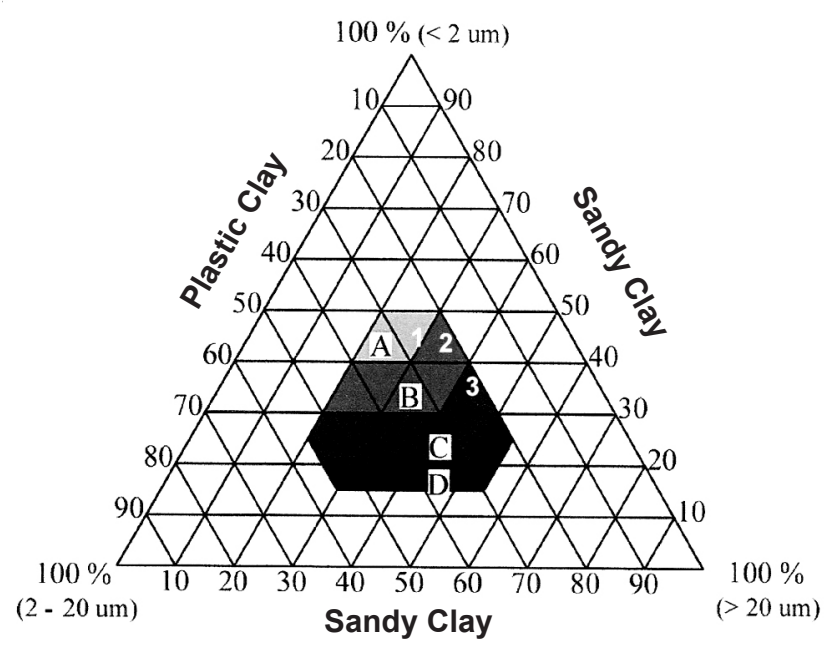

Figure 3: Granulometric classification of the clay/SCBA waste mixtures according to Winkler diagram. 1 - KC0; 2 - KC10; 3 KC20.

[Figura 3: Classificação granulométrica das misturas argilal resíduo de CBCA de acordo com o diagrama de Winkler. 1 - KCO; 2-KC10; 3 - KC20.]

The plasticity of the clay/SCBA waste mixtures (Fig. 4) was evaluated by the Atterberg's consistency limits. The Atterberg plastic index (PI) was determined by PI = UPL LPL, in which UPL is the upper plastic limit and LPL is the lower plastic limit. The incorporation of SCBA waste into clay body reduces its global plasticity. In fact, the SCBA waste is a non-plastic material rich in silica particles. It was found that the upper plastic limit varies from 63.6 to $54.9 \%$, lower plastic limit (water of plasticity) from 30.8 to $29.3 \%$, and the Atterberg plastic index from 33.5 to $25.6 \%$. These values are within the adequate range for industrial production of clay-based products [20]. Thus, the SCBA waste could be incorporated in moderate amounts into plastic clay body as

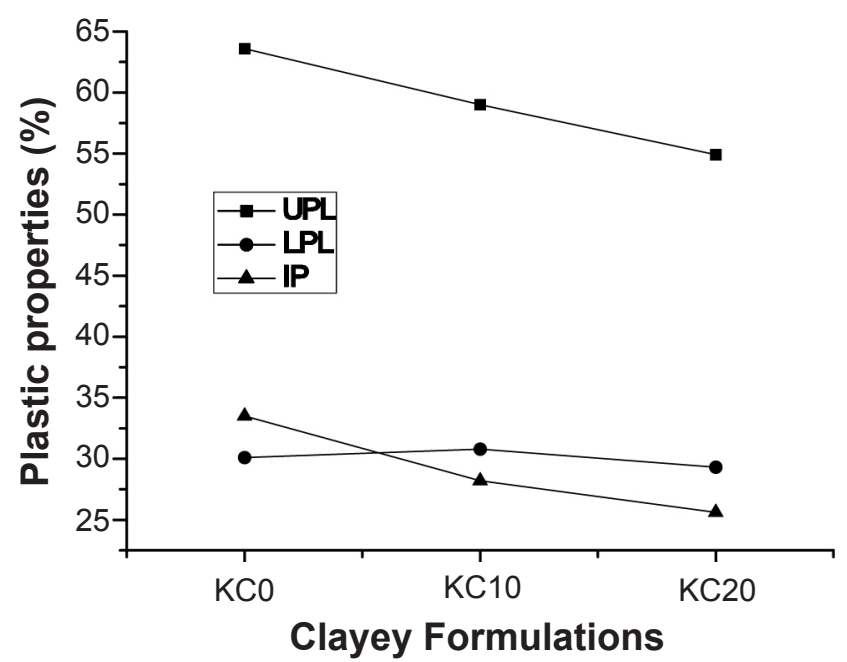

Figure 4: Atterberg consistency limits for the clayey formulations. [Figura 4: Limites de consistência de Atterberg para as formulações argilosas.] a non-plastic component, which provides structural support that helps to retain shape during drying and firing steps.

The physical properties of the red ceramic pieces in the dried state at $110^{\circ} \mathrm{C}$ are presented in Table III. The results demonstrate that no significant differences in the drying shrinkage and drying density of the pieces were observed among the studied clayey formulations. In addition, the shrinkage and density values for all clay ceramic pieces satisfy the safe limits for industrial production of red ceramic.

Table III - Physical properties of the red ceramic pieces in the dried state at $110^{\circ} \mathrm{C}$.

[Tabela III - Propriedades físicas das peças de cerâmica vermelha no estado seco a $110^{\circ} \mathrm{C}$.]

\begin{tabular}{lcc}
\hline Formulation & $\begin{array}{c}\text { Drying Shrinkage } \\
(\%)\end{array}$ & $\begin{array}{c}\text { Drying Density } \\
\left(\mathrm{g} / \mathrm{cm}^{3}\right)\end{array}$ \\
\hline $\mathrm{KC} 0$ & $0.10 \pm 0.06$ & $1.75 \pm 0.02$ \\
$\mathrm{KC5}$ & $0.09 \pm 0.04$ & $1.71 \pm 0.02$ \\
$\mathrm{KC10}$ & $0.06 \pm 0.04$ & $1.72 \pm 0.02$ \\
$\mathrm{KC} 15$ & $0.08 \pm 0.04$ & $1.67 \pm 0.02$ \\
$\mathrm{KC} 20$ & $0.05 \pm 0.03$ & $1.70 \pm 0.02$ \\
\hline
\end{tabular}

Figs. $5 \mathrm{a}$ and $\mathrm{b}$ show the XRD patterns of the $\mathrm{KC} 0$ and $\mathrm{KC} 10$ formulations fired at different temperatures. It can be observed in Fig. 5a that at $700{ }^{\circ} \mathrm{C}$ the peaks of kaolinite, gibbsite, and goethite are not seen. Kaolinite is transformed into amorphous metakaolinite [21]. Gibbsite has likely been transformed into a transition alumina phase, while goethite has been transformed in hematite. The peaks of illite/mica and potash feldspar remain up to $900{ }^{\circ} \mathrm{C}$, while the peaks of quartz are present during all firing temperatures. At $1100{ }^{\circ} \mathrm{C}$ peaks of mullite, hematite, and cristobalite appear. Specimens containing SCBA waste (KC10 sample) showed a quite different phase evolution as revealed by the XRD patterns (Fig. 5b). Quartz and calcium phosphate peaks are observed for all firing temperatures. At $700{ }^{\circ} \mathrm{C}$, quartz, illite/mica, cristobalite, calcium phosphate, and potassium carbonate appear. At $900{ }^{\circ} \mathrm{C}$, the peaks of potassium carbonate have disappeared. At $1100^{\circ} \mathrm{C}$, mullite peaks were detected.

Figs. 6a-c show the SEM micrographs of the fired specimens at $1100{ }^{\circ} \mathrm{C}$ prepared with different amounts of added SCBA waste. The effect of the incorporation of SCBA waste (Figs. 6b-c) is to increase the open porosity of the fired specimens. This is associated with high concentrations of silica particles and organic matter in the SCBA waste sample. In addition, the SCBA waste containing specimens (Fig. 6b) showed microcracks probably related to the inversion $\beta$-quartz ${ }^{\circledR} \alpha$-quartz during cooling.

Figs. 7-10 show the changes observed in the technological properties (linear shrinkage, apparent density, water absorption, and tensile strength) of the red ceramic pieces as a function of the waste additions and firing temperature. The results demonstrate clearly that the technological properties are strongly dependent on both the waste additions and firing temperature. 

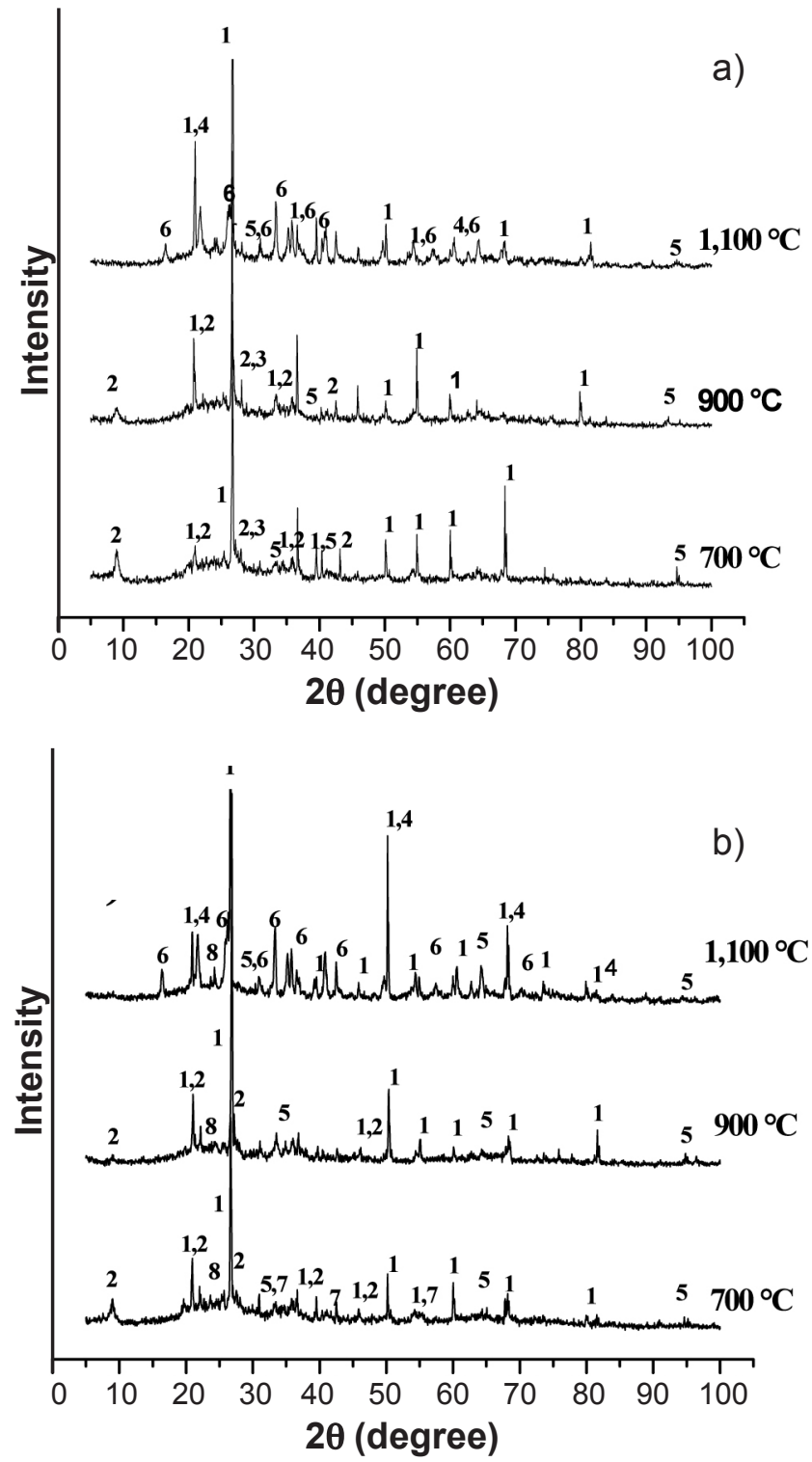

Figure 5: XRD patterns for the red ceramic pieces fired at different temperatures. a) $\mathrm{KC} 0$; and b) $\mathrm{KC} 10.1$ - quartz; 2 - illite/mica; 3 - potash feldspar; 4 - cristobalite; 5 - hematite; 6 - mullite 7 potassium carbonate -8 ; calcium phosphate.

[Figura 5: Difratogramas de raios $X$ das peças de cerâmica vermelha queimadas em diferentes temperaturas. a) KCO e b) KC10. 1 - quartzo; 2 - illita/mica; 3 -feldspato potássico; 4 cristobalita; 5 - hematita; 6 - mullita; 7 - carbonato de potássico; 8 - fosfato de cálcio.]

Fig. 7 shows the linear shrinkage of the red ceramic pieces fired at different temperatures. This property is very important for the dimensional control of the finished red ceramic products. The linear shrinkage increases continuously with the increase of the firing temperature for all SCBA waste additions. The ceramic pieces presented low firing shrinkage up to $1000{ }^{\circ} \mathrm{C}(0.61-2.80 \%)$, resulting in good dimensional control. At $1100{ }^{\circ} \mathrm{C}$, however, a higher range of values is measured (6.01-8.33\%). According with the literature [22] for temperatures up to $1000{ }^{\circ} \mathrm{C}$, the red ceramic pieces are sintered predominantly via solid state
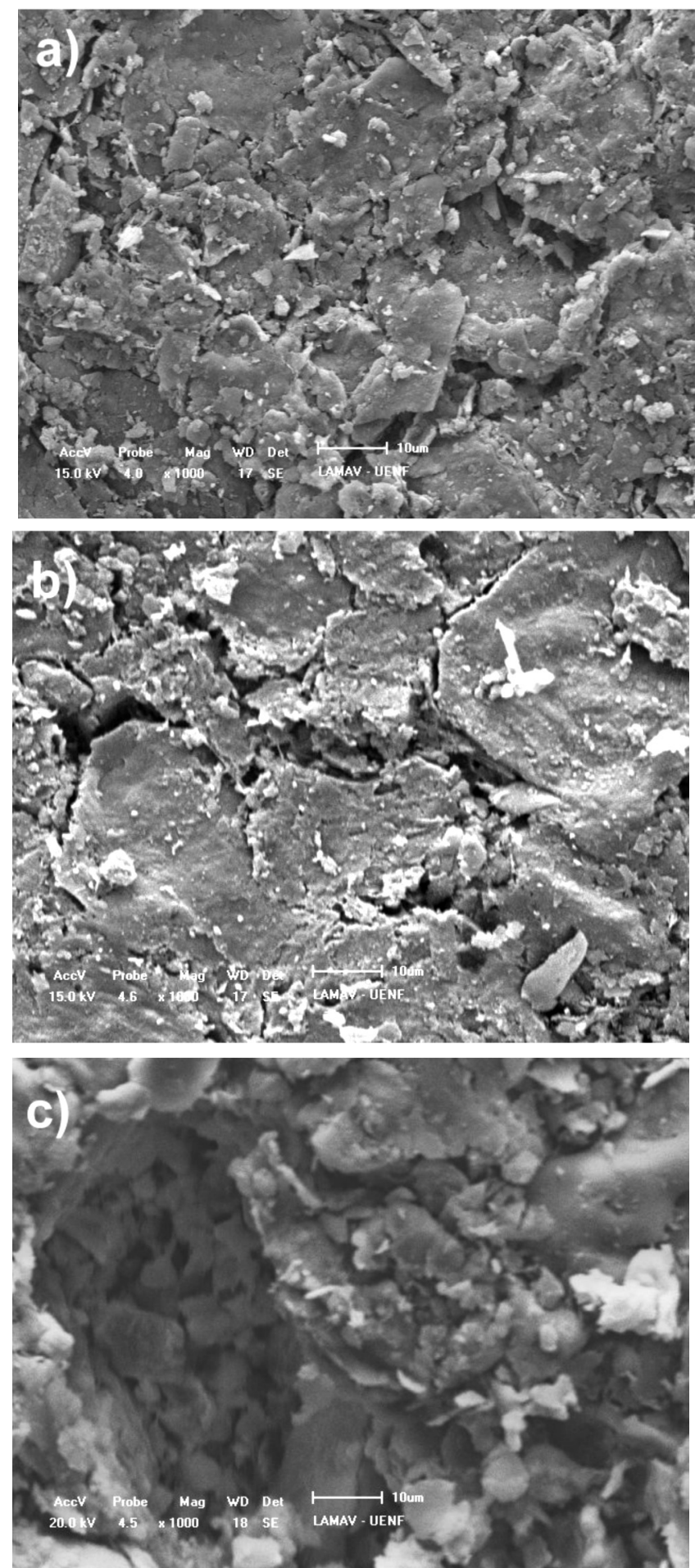

Figure 6: SEM micrographs of the fired specimens at $1100{ }^{\circ} \mathrm{C}$ : a) $\mathrm{KC0}$; b) KC10; and c) KC20.

[Figura 6: Micrografias obtidas via MEV das amostras queimadas em $1100{ }^{\circ} \mathrm{C}$ : a) $\mathrm{KCO}$; b) $\mathrm{KC} 10$; e c) $\left.\mathrm{KC} 20.\right]$

sintering mechanism. Above $1000{ }^{\circ} \mathrm{C}$ the specimens are sintered prevalently by viscous flow [22, 23]. This explains the higher values of linear shrinkage. It can also be seen in Fig. 7 that the shrinkage of the SCBA waste containing pieces is lower than that in the pure clay pieces ( $\mathrm{KC} 0$ formulation). In fact, as shown in Fig. 4, the incorporation of the SCBA 


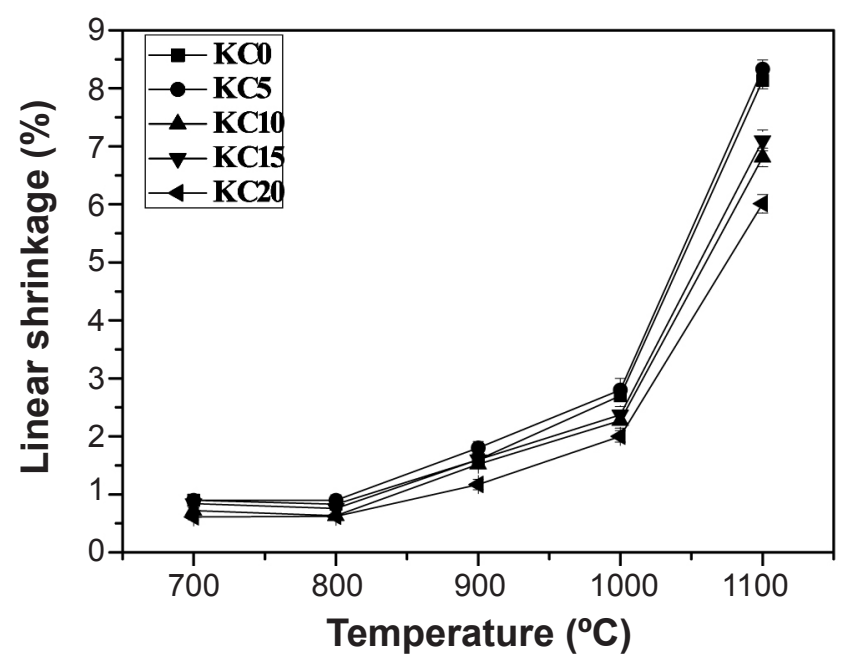

Figure 7: Linear shrinkage as a function of SCBA waste amount for all temperatures.

[Figura 7: Retração linear como uma função da quantidade de resíduo de CBCA para todas as temperaturas.]

waste rich in silica particles reduces the plasticity of the used common clay. Thus, the SCBA waste improved the dimensional control of the red ceramic pieces.

The apparent density of the fired pieces is shown in Fig. 8. It can be seen that the density decreases for higher SCBA waste additions. This result is in accordance with the linear shrinkage values. The pieces fired up to $1000{ }^{\circ} \mathrm{C}$ presented the lowest apparent density $\left(1.51-1.70 \mathrm{~g} / \mathrm{cm}^{3}\right)$, which is due to the combined inverse effects of sintering and weight loss. At $1100^{\circ} \mathrm{C}$, however, a substantial increase in apparent density $\left(1.77-1.94 \mathrm{~g} / \mathrm{cm}^{3}\right)$ was observed, which is in line with the vitrification that helps to reduce the open porosity of the red ceramic pieces.

Fig. 9 shows the curve of tensile strength of the fired pieces. As expected, the effect of the firing temperature

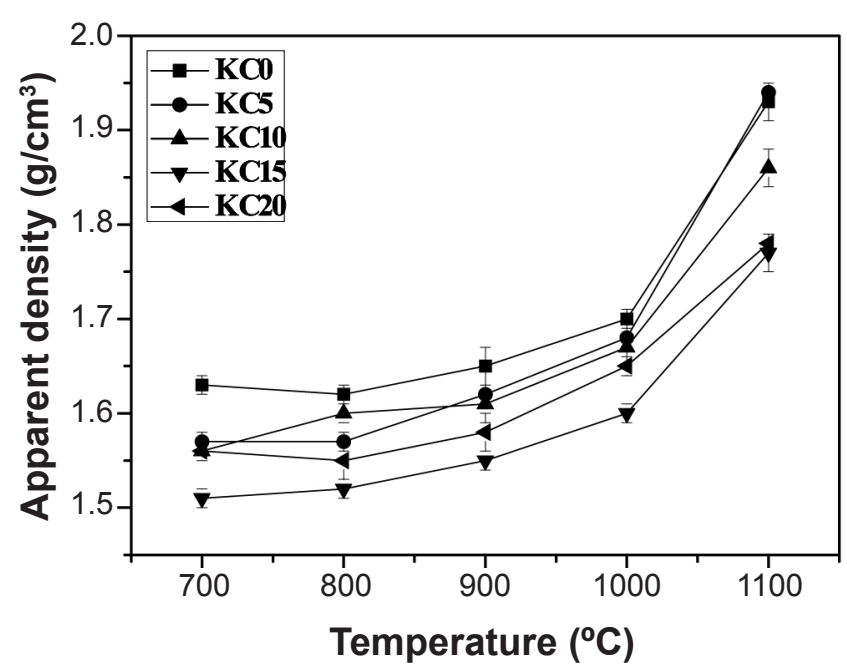

Figure 8: Apparent density as a function of SCBA waste amount for all temperatures.

[Figura 8: Massa específica aparente como uma função da quantidade de resíduo de CBCA para todas as temperaturas.] was to increase the mechanical strength mainly above 1000 ${ }^{\circ} \mathrm{C}$. This behavior is in accordance with the densification behavior during sintering (Figs. 7 and 8). The results also showed that the SCBA waste additions tend to decrease the mechanical strength of the clay ceramic pieces. This signifies that high amounts of SCBA waste should be avoided because it tends to severely reduce the mechanical strength of the red ceramic pieces.

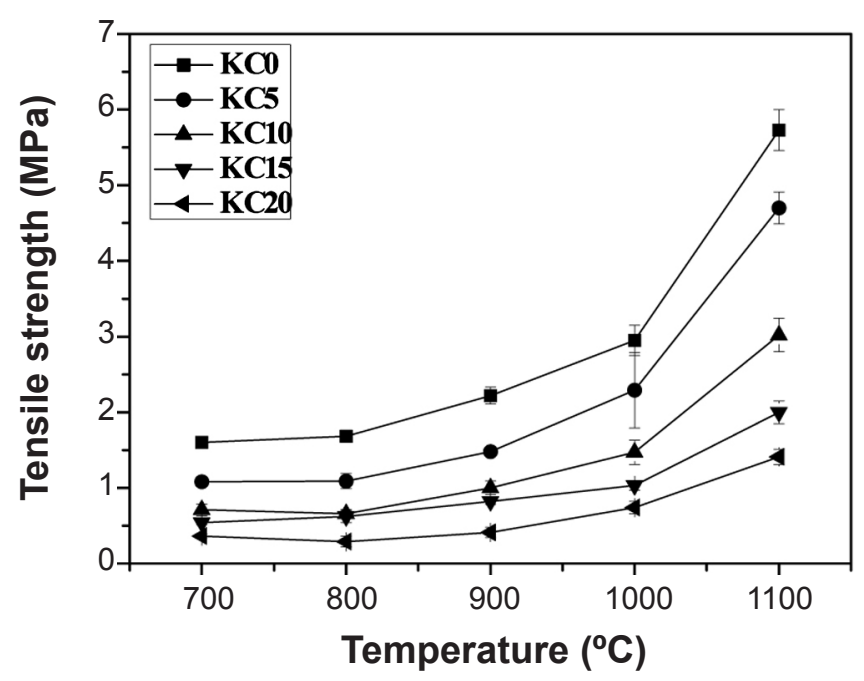

Figure 9: Tensile strength as a function of SCBA waste amount for all temperatures.

[Figura 9: Resistência à tração como uma função da quantidade de resíduo de CBCA para todas as temperaturas.]

Fig. 10 shows the water absorption of the fired pieces. The water absorption is related to the volume of the open pores, that is, the pores that are connected with the specimen's surface. As expected, the water absorption increased for higher SCBA waste additions. This behavior agrees with the observation of the microstructure (Fig. 6) and apparent density (Fig. 8). It can also be seen in Fig. 10 that the water absorption behaves differently below and above $1000{ }^{\circ} \mathrm{C}$. In the $700-1000{ }^{\circ} \mathrm{C}$ temperature range, the water absorption presented only a small variation $(22.76-27.40 \%)$. At $1100{ }^{\circ} \mathrm{C}$, a significant decrease in water absorption is measured (14.45$19.50 \%$ ), caused by open-pore partial closure. The water absorption (wa) is also a physical property that defines the class to which any clay-based building materials suits. The reference values of water absorption currently accepted in the industrial practice for manufacture of bricks and roofing tiles are: optimal range $(\mathrm{wa}=12-24 \%)$ and acceptable range (wa $=10-30 \%)$ [20]. In this study the specification for bricks and roofing tiles has been attained in the following firing temperatures: i) $\mathrm{KC} 0$ (optimal range between 700 and $1100{ }^{\circ} \mathrm{C}$ ); ii) $\mathrm{KC} 5$ and $\mathrm{KC10}$ (optimal range between 1000 and $1100{ }^{\circ} \mathrm{C}$ and acceptable range between 700 and $900{ }^{\circ} \mathrm{C}$ ); and iii) $\mathrm{KC} 15$ and $\mathrm{KC} 20$ (optimal range at $1100{ }^{\circ} \mathrm{C}$ and acceptable range between 700 and $1000{ }^{\circ} \mathrm{C}$ ).

The colour and appearance of the red ceramic pieces in the dry state and fired at different temperatures were 


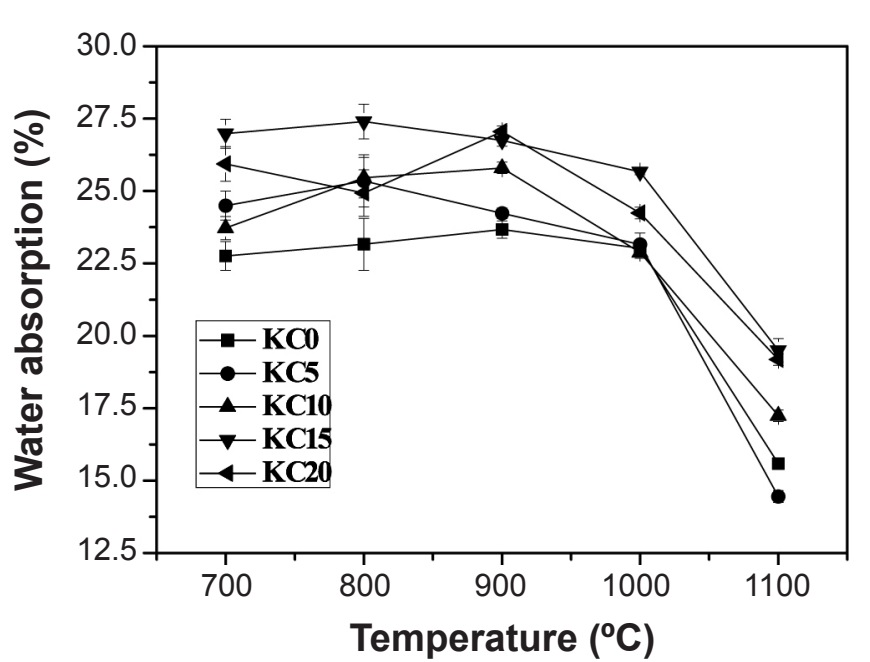

Figure 10: Water absorption as a function of SCBA waste amount for all temperatures.

[Figura 10: Absorção de água como uma função da quantidade de resíduo de CBCA para todas as temperaturas.]

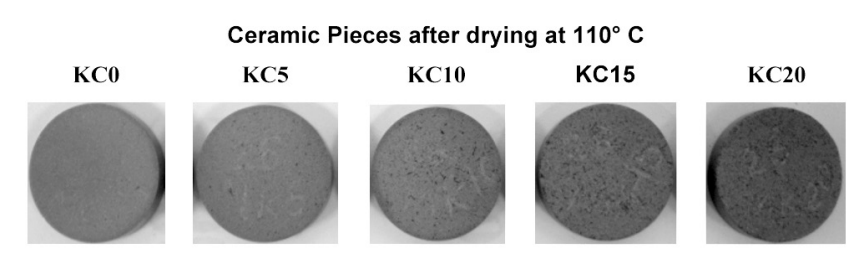

Figure 11: Variation in colour of the ceramic pieces after drying at $1100^{\circ} \mathrm{C}$.

[Figura 11: Variação na cor das peças cerâmicas após secagem a $\left.1100{ }^{\circ} \mathrm{C}.\right]$

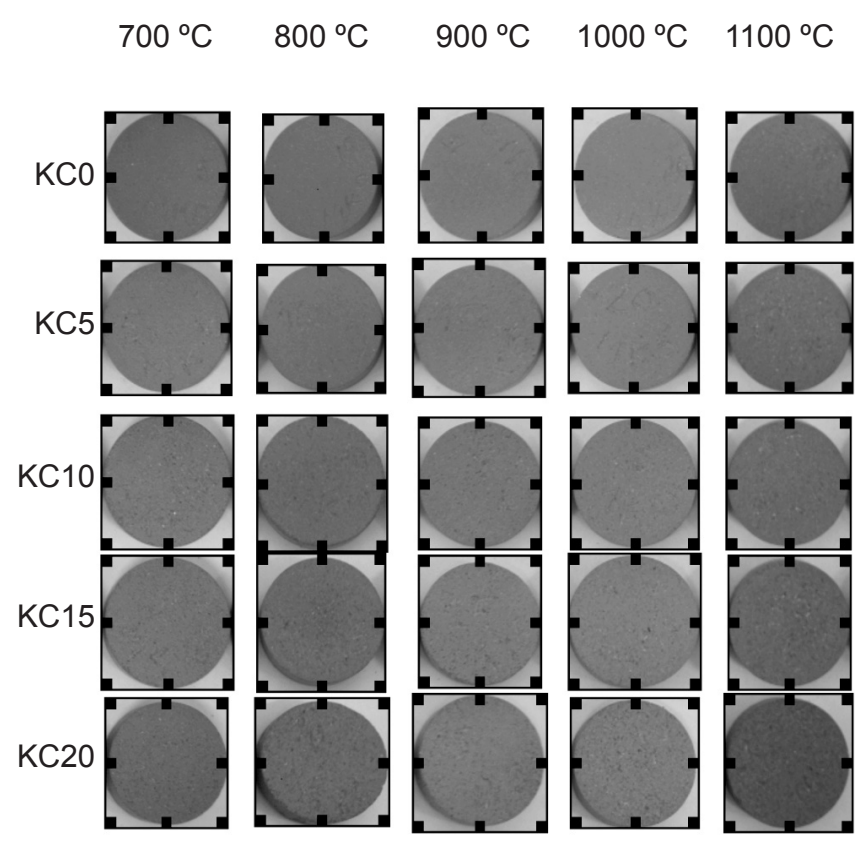

Figure 12: Variation in colour of the ceramic pieces after firing at different temperatures.

[Figura 12: Variação na cor das peças cerâmicas após queima em diferentes temperaturas.] examined. All ceramic pieces in the dried state (at $110{ }^{\circ} \mathrm{C}$ ), as shown in Fig. 11, presented brown colour. However, the incorporation of SCBA waste tends to modify the hue of the pieces toward darken brown colour. In fact, the pieces have small black's dots that characterize the presence of SCBA waste. Despite this, the incorporation of SCBA waste had little influence on the colour of the fired pieces (Fig. 12). The pieces showed reddish-yellow colour typical of red ceramic materials. At $1100{ }^{\circ} \mathrm{C}$, however, the ceramic pieces become slightly darker. This can is directly associated with iron oxide present in the used clayey body. It can also be observed that no red ceramic piece has shown any indication of surface stains due to the incorporation of SCBA waste. Thus, the firing colour of the fired pieces is suitable for red ceramic production.

\section{CONCLUSIONS}

This work has demonstrated that the SCBA waste could be incorporated as a low cost raw material to produce red ceramics (bricks and roofing tiles). This is very important because the incorporation of the SCBA waste into clay body can contribute greatly to reduce the environmental impacts caused by the sugarcane industry worldwide. The SCBA waste is chemically rich in silica particles $\left(\mathrm{SiO}_{2}\right)$, but also contains calcium phosphate, potassium carbonate, mullite, cristobalite, and hematite as accessory minerals. It is a nonplastic material that significantly affects the granulometric and plastic behavior of the used clay body. It was found that the SCBA waste influenced the technological properties, microstructure, and phase evolution of the fired red ceramic pieces. The incorporation of SCBA waste into clay body tends to improve the dimensional stability of the red ceramic pieces. The water absorption specifications for bricks and roofing tiles have been achieved in the firing temperature range employed. The results also showed that the mechanical strength was severely reduced for additions above $10 \mathrm{wt} . \%$ of SCBA waste. For this reason, this study suggests that only moderate additions of SCBA waste should be used in the production of red ceramic.

\section{ACKNOWLEDGEMENTS}

The authors would like to thank CNPq and FAPERJ for the financial support and Usina Sapucaia by the supply of SCBA waste.

\section{REFERENCES}

[1] CONAB, Acompanhamento da Safra Brasileira: CanaDe-Açúcar, Brasília, DF (2012).

[2] K. S. Shanmukharadhya, K. Ramachandran, J. Energy Inst. 82 (2009) 120-122.

[3] B. R. Stanmore, Waste Biomass Valor. 1 (2010) 77-89.

[4] FIESP, Ampliação da Oferta de Energia Através da Biomassa (Bagaço de Cana-De-Açúcar), S. Paulo, SP (2001). 
[5] L. A. Díaz Rodríguez, R. Torrecillas, Bol. Soc. Esp. Cerám. Vídrio 41 (2002) 459-470.

[6] C. N. Djangang, A. Elimbi, U. C. Melo, C. Nkoubou, G. Leconte, J. Yuon, J. P. Bonnet, D. Njopwowo, Ind. Ceram. 27 (2007) 79-88.

[7] H. Baccour, M. Medhioub, F. Jamoussi, T. Mhiri, A. Daoud, Mater. Charact. 59 (2008) 1613-1622.

[8] R. R. Menezes, G. A. Neves, H. C. Ferreira, Rev. Bras. Eng. Agrí. Amb. 6, 2 (2002) 303-313.

[9] K. C. P. Faria, Master Thesis, UENF-PPGECM, Campos dos Goytacazes, RJ (2011).

[10] E. S. Freitas, Master Thesis, UENF-PPGEC, Campos dos Goytacazes, RJ (2005).

[11] S. R. Teixeira, A. E. Souza, G. T. A. Santos, A. F. V. Pena, J. Am. Ceram. Soc. 91 (2008) 1883-1887.

[12] V. S. Aigbodion, S. B. Hassan, T. Aux, G. B. Nyior, J. Miner. Mater. Charac. Eng. 9 (2010) 67-77.

[13] K. C. P. Faria, R. F. Gurgel, J. N. F. Holanda, J. Environ. Manag. 101 (2012) 7-12.

[14] F. Chen, Z. Sun, J. Xu, Int. J. Rock Mech. Min. Sci. 38,
(2001) 475-479.

[15] J. F. Martirena, H. B. Middendorf, M. Gehrke, H. Buldelmann, Cem. Concr. Res. 28, 11 (1998) 1525-1536.

[16] J. Payá, J. Monzó, M. V. Borrachero, L. Diaz-Pinzón, L. M. Ordónez, J. Chem. Technol. Biotechnol. 77, 3 (2002) 321-325.

[17] G. C. Cordeiro, F. R. D. Toledo, E. M. R. Fairbair, Quim. Nova 32, (2009) 82-86.

[18] M. O. Paula, I. F. F. Tinôco, C. S. Rodrigues, E. N. Silva, C. F. Souza, Rev. Bras. Eng. Agrí. Amb. 13, 3 (2009) 353-57.

[19] H. G. F. Winkler, Ber. DKG 31 (1954) 337-343.

[20] M. Dondi, Int. Ceram. J. (2003) 55-59.

[21] P. S. Santos, Ciência e Tecnologia de Argilas, Vol. 1, $2^{\text {a }}$ Ed., Edgard Blücher Ltda, S. Paulo, SP (1989).

[22] F. A. C. Milheiro, M. N. Freire, A. G. P. Silva, J. N. F. Holanda, Ceram. Int. 31 (2005) 757-763.

[23] J. S. Reed, Principles of Ceramic Processing, $2^{\text {nd }}$ Ed., Wiley Interscience, New York, (1995).

(Rec. 26/03/2013, Ac. 27/04/2013) 